\title{
A NEWLY DISCOVERED WHITMAN POEM
}

\author{
JEROME LOVING
}

Two WEeks AFTER THE PUblication of Walt Whitman's Franklin Evans: or The Inebriate in The New World, editor Park Benjamin published "A Sketch." Appearing under "Original Poetry" in the issue of December 10,1842 , the poem was signed "W." and has not until now been known or identified as one of Whitman's early poems. ${ }^{1}$ Benjamin was outspoken as a journalist and quarreled with just about everybody in and around Naussau Street, where newspaper row was then located. This included Whitman at one point, but Benjamin thought highly enough of Whitman's literary skills to describe the ex-editor of the Aurora in advertisements for Franklin Evans as a "Popular American Author." $\mathrm{He}$ continued to admire Whitman even after the publication of his controversial editions of Leaves of Grass in the 1850 s. $^{2}$ The poem he published on December 10 resembles in theme and metrics Whitman's "Each Has His Grief" and "The Punishment of Pride," which Benjamin had published in The New World in 1841: all three poems dealt with the old idea that the next life awaits to relieve us from the burdens of this one, and all were cadenced out in iambic tetrameter, the favored rhythm of the 1830s and 1840s and one of Ralph Waldo Emerson's frequent meters. The poem also bears a strong kinship with Whitman's earliestknown poem, "Our Future Lot," which was printed in the Long Island Democrat of October 31, 1838, from the poet's own newspaper, The Long-Islander. In "Our Future Lot," also published in 1842 as "Time to Come" in the Democratic Review and the Aurora, ${ }^{3}$ we get the same affirmation of the afterlife found in the ending of "A Sketch." In "Our Future Lot" we have the statement that "The flickering taper's glow shall change / To bright and starlike majesty, / Radiant with pure and piercing light / From the Eternal's eye." "A Sketch" concludes with the "sweet star, whose golden gleam, / Pierces the tempest's gathering gloom, / In the rich radiance of its beam" to tell "of light beyond the tomb!"

More important, “A Sketch" is very likely Whitman's first seashore poem, anticipating, albeit vaguely and in the convention of the times, such later and great poems as "Out of the Cradle Endlessly Rocking" (1859), "As I Ebb'd with the Ocean of Life" (1860), and "Out of the Rolling Ocean the Crowd" (1865). The only earlier hint of a seashore setting is found in "My Departure," published in the Long Island Democrat of November 27, 1839, and-with slight revisions-as "Death 
of the Nature-Lover" in Brother Fonathan, March 11, 1843, where it is merely "A bay" seen "At distance through the opening trees" and partially obscured "by misty vapours curled." We know from Thomas L. Brasher's invaluable edition of The Early Poems and the Fiction that Whitman revised and reprinted in the early 1840s in New York-where he was first making his way into the literary world and onto the pages of the prestigious Democratic Review-poems written in the late 1830s on Long Island. "A Sketch," therefore, may be a re-writing of "My Departure" with the notable addition of a dead lover. Here is the entire poem, as it appeared in The New World:

\section{A SKETCH}

"The trail of the serpent is at times seen in every man's path."

Upon the ocean's wave-worn shore I marked a solitary form,

Whose brooding look, and features wore The darkness of the coming storm!

And, from his lips, the sigh that broke, So long within his bosom nursed,

In deep and mournful accents spoke, Like troubled waves, that shining burst!

And as he gazed on earth and sea, Girt with the gathering night; his soul,

Wearied and life-worn, longed to flee, And rest within its final goal!

He thought of her whose love had beamed, The sunlight of his ripened years;

But now her gentle memory seemed To brim his eye with bitter tears!

"Oh! thou bless'd Spirit!" thus he sighed"Smile on me from thy realm of rest!

My dark and doubting spirit guide, By conflict torn, and grief oppressed!

Teach me, in every saddening care, To see the chastening hand of Heaven;

The Soul's high culture to prepare,

Wisely and mercifully given!

"Could I this sacred solace share,

'Twould still my struggling bosom's moan;

And the deep peacefulness of prayer,

Might for thy heavy loss atone!

Earth, in its wreath of summer flowers, And all its varied scenes of joy,

Its festal halls and echoing bowers, No more my darkened thoughts employ. 


\footnotetext{
"But here, the billow's heaving breast, And the low thunder's knelling tone, Speak of the wearied soul's unrest, Its murmuring, and conflicts lone!

And yon sweet star, whose golden gleam, Pierces the tempest's gathering gloom, In the rich radiance of its beam, Tells me of light beyond the tomb!"
}

Because of Emerson's fondness for iambic tetrameter, it would be nice to think we also have here the earliest-known evidence of Emerson's influence on Whitman's poetry, but the young journalist probably had not read any of Emerson's poems, which - with the exception of the few in Rufus Wilmot Griswold's anthologies published in the early 1840s - did not officially make their debut until 1847 with Emerson's first volume of verse. More probably, Whitman's primary models were the published poets of the day in The New World or Brother Fonathan (Benjamin's main competition in the semi-literary magazine market of the early 1840s)-poets like Benjamin himself or Nathaniel P. Willis, both of whom hammered out their verse in tetrameters. Perhaps his main model for this poem, at least, was Edgar Allan Poe's "To Helen," which had been first published in 1831. That poem in its own fashion is also a seashore poem in which the subject's beauty bears the "weary, way-worn wanderer" to "his own native shore." Whitman's poem opens upon a "wave-worn shore" and closes with "the wearied soul's unrest." The future "Solitary Singer," as he has been called by Gay Wilson Allen, looks upon a "solitary form" who is obviously the speaker's Doppelgänger. This double narration anticipates Whitman's voyeuristic point of view not only in "Out of the Cradle" but in Section 11 of "Song of Myself," where the sexually frustrated woman of twenty-eight years spies on an equal number of naked male swimmers. The object of loss in "A Sketch" is a woman (or so it would seem, although another poem, "Once I Pass'd Through a Populous City" [1860], also seemed to be about a woman until a biographer discovered Whitman's altered draft copy). ${ }^{4}$ It has been argued elsewhere that such a late poem as "Out of the Rolling Ocean the Crowd" is also about the loss of a beautiful woman, or at least a married one whom Whitman allegedly said he would have wed had she been "free." In the case of "Out of the Cradle," the separation is also heterosexual, between a "he-bird" and a "she-bird." Yet there is thus far no biographical evidence during this period to suggest Whitman's romantic involvement with a woman (or anyone, for that matter), and as in the case of "Out of the Cradle" and "As I Ebb'd," the narrator of "A Sketch" is ultimately concerned with the significance of love in the context of the unknown, which is pondered in the logocentric, Judeo-Christian tradition. 
The poem shows no response to Emerson's closing statement in "Nature and the Powers of the Poet," which Whitman had heard in New York in March of 1842, that "New topics, new powers, a new spirit arise, which threaten to abolish all that was called poetry" in the past ${ }^{6}$-what would become in "The Poet" of Essays: Second Series (1844) a call for a "meter-making argument." Yet neither did Emerson follow his own advice in Poems (1847), where many of the verses employ the same conventional meter and rhyme schemes found in "A Sketch." What is remarkable about "A Sketch" in terms of its claim as part of the poet's early canon is not its rhyme and meter but the fact that it reveals - perhaps for the first time in the poetry-the loneliness found in parts of "Song of Myself," the "Calamus" poems, and the "Sea-Drift" poems. "A Sketch" reveals, even in its poetic conventionality, the private poet who would make public his boundless affection for the one in the many, for that representative lover who, it appears, eluded the poet all his life. While the public poet, as well as the journalist and fiction writer, continued throughout the decade to give out conventional advice to working men and women, apprentices and youths, and public servants, the private poet continued to develop.

Whitman's first great poems took him, in a sense, away from Paumanok, or the shores of Long Island where he grew up. That is to say, poems like "Song of Myself," "I Sing the Body Electric," and "Crossing Brooklyn Ferry," are clearly stamped with Emerson's transcendentalism - albeit with a Brooklyn body. It was only in the third edition, as Whitman neared the end of the 1850 s and encountered his "slough," or midlife crisis, that he returned to Paumanok and the image of the seashore to symbolize the ever-shifting boundary between life and death. Here personal identity was not so readily absorbed into the Oversoul. Whitman may have experienced a similar period of crisis in the 1840s. His detailed familiarity with the depression of alcoholism and the methods of the temperance movement (including the distinction, for example, between the "Old" and "New" temperance pledges) in Franklin Evans suggests (along with other evidence I am now developing in a biography) that Whitman, like his tippling protagonist from the countryside of Long Island, may have had a drinking problem during his first year in the big city of Manhattan. Certainly other members of his immediate family did.

In "A Sketch" the narrator is a solitary lover who-like his successor in "Out of the Cradle"-broods through another who has lost his mate. In 1842, by the time of publication of "A Sketch," Whitman was twenty-three and out of full-time newspaper employment since the previous spring, a holding pattern that would last for the next three years. In the first stanza of the poem, the narrator speaks of "the darkness of the coming storm" and looks for salvation in the romantic 
concept of Poe's Helen, whose beauty-not exactly her body-makes everything all right. As in "Each Has His Grief" in The New World of November 20,1841, ${ }^{7}$ Death is the ultimate reconciler of earthly conflict. We are like that "wearied child"

\author{
That over field and wood all day \\ Has ranged and struggled, and at last, \\ Worn out with toil and play, \\ Goes up at evening to his home, \\ And throws him, sleepy, tired, and sore, \\ Upon his bed, and rest him there, \\ His pain and trouble o'er.
}

A year later in "A Sketch," the "solitary form" is described as "By conflict torn, and grief oppressed!" - which may or may not be the sole result of the death of his lover. He yearns to see "the chastening hand of Heaven" in the turmoil and grief of life. Much of this sentiment echoes the platitudes of the day, yet Whitman was perhaps beginning to break through them in his poetry and fiction. He published the first two chapters of his second novella or temperance tract on January 28, 1843 (the only evidence of its being a temperance novel is that these chapters appeared in the Washingtonian, an organ representing America's renewed interest in this reform in the 1840s). This was to be "The Madman," but no subsequent chapters have been found. Whitman may have abandoned the project before it took him beyond the standards of the "evening lamp" which forbade anything but the most abstract and sentimental depictions of heterosexual love. The tale presents two male figures, Richard Arden and Pierre Barcoure, who "became near and dear to one another." 8 Of course, Whitman's concept of "Adhesiveness" did not send then the same signals as it does today-in the century ushered in by the Oscar Wilde sodomy trials of 1895 . Nevertheless, the American world of letters was not prepared for the "Calamus" sentiment in the 1840s, and perhaps Whitman was yet unprepared as well for the intimacy this story promises. In "A Sketch" it would be enough to love through another, to allow "the billow's heaving breast / And the low thunder's knelling tone, / Speak of the wearied soul's unrest, / Its murmurings, and conflicts lone!”

Texas AE'M University

\title{
NOTES
}

1 For the most recent collection of the poet's pre-1855 poetry, see The Early Poems and the Fiction, ed. Thomas L. Brasher (New York: New York University Press, 1963). See Figure 1 for a photograph of the printed poem. I have silently reconstructed the broken exclamation point in line 4, but I have not been able to identify the source of Whitman's 
epigraph and suspect it may be an editorial insertion by Benjamin. For their assistance, I would like to thank Rudolph Ellenbogen and Andrea Baumgardner of the Rare Book and Manuscript Library, Columbia University, where I discovered the poem.

2 See Merle M. Hoover, Park Benjamin: Poet and Editor (New York: Columbia University Press, 1948); and Poems of Park Benjamin (New York: Columbia University Press, 1948).

3 My assertion that "Time to Come" appeared in the Democratic Review (not noted in Brasher or in Walt Whitman of the New York Aurora, ed. Joseph Jay Rubin and Charles H. Brown [State College, PA: Bald Eagle Press, 1950]) is based on a statement in the Aurora of April 9, 1842. I have not yet located the poem in the Democratic Review.

4 Gay Wilson Allen, The Solitary Singer: A Critical Biography of Walt Whitman (New York: Macmillan, 1955) and Emory Holloway, Whitman: An Interpretation in Narrative (New York: Knopf, 1926). For the story of Holloway's discovery of the manuscript and its biographical results, see Jerome Loving, "Emory Holloway and the Quest for Whitman's 'Manhood,' 'Walt Whitman Quarterly Review, 11 (Summer, 1993), 1-17.

5 Uncollected Poetry and Prose of Walt Whitman, ed. Emory Holloway (New York: Doubleday, 1921), 1:lviii, n. 15; and Leaves of Grass: Reader's Comprehensive Edition, ed. Sculley Bradley and Harold W. Blodgett (New York: New York University Press, 1965), 106n.

6 Early Lectures of Ralph Waldo Emerson, ed. Robert E. Spiller and Wallace E. Williams (Cambridge: Harvard University Press, 1972), 3:364; see also Jerome Loving, Emerson, Whitman, and the American Muse (Chapel Hill: University of North Carolina Press, 1982), 7-11, passim.

7 The poem was published as "We All Shall Rest at Last" in the Long Island Democrat of July 14, 1840. As with "Our Future Lot," this poem may also have appeared in the Long-Islander, but there is so far no way of telling since copies of Whitman's first journalistic venture are not known to be extant. We know of the origin of "Our Future Lot" only because it is stated in the Long Island Democrat; see The Uncollected Poetry and Prose of Walt Whitman, 1:1, n. 1.

8 The Early Poems and the Fiction, 240-243. 